\title{
Using models to establish the financially optimum strategy for Irish dairy farms
}

\author{
E. Ruelle, ${ }^{* 1}$ L. Delaby, $†$ M. Wallace, $\ddagger$ and L. Shalloo* \\ *Teagasc, Animal and Grassland Research and Innovation Centre, Moorepark, Fermoy, Co. Cork, Ireland \\ †INRA Agrocampus Ouest, UMR 1348, Physiologie, Environnement et Génétique pour l'Animal et les Systèmes d'Elevage, Domaine de la Prise, \\ 35590 Saint Gilles, France \\ ‡School of Agriculture, Food, and Rural Development, Newcastle University, Newcastle upon Tyne, NE1 7RU, United Kingdom
}

\section{ABSTRACT}

Determining the effect of a change in management on farm with differing characteristics is a significant challenge in the evaluation of dairy systems due to the interacting components of complex biological systems. In Ireland, milk production is increasing substantially following the abolition of the European Union milk quota regime in 2015. There are 2 main ways to increase the milk production on farm (within a fixed land base): either increase the number of animals (thus increasing the stocking rate) or increase the milk production per animal through increased feeding or increased lactation length. In this study, the effect of increased concentrate feeding or an increase in grazing intensity was simulated to determine the effect on the farm system and its economic performance. Four stocking rates $(2.3,2.6,2.9$, and $3.2 \mathrm{cow} / \mathrm{ha})$ and 5 different concentrate supplementation strategies (0, $180,360,600$, and $900 \mathrm{~kg}$ of dry matter/lactation) resulting in 20 different scenarios were evaluated across different milk, concentrate, and silage purchase prices. Each simulation was run across 10 yr of meteorological data, which had been recorded over the period 2004 to 2013. Three models - the Moorepark and St Gilles grass growth model, the pasture-based herd dynamic milk model, and the Moorepark dairy systems modelwere integrated and applied to simulate the different scenarios. Overall, this study has demonstrated that the most profitable scenario was a stocking rate of 2.6 cow/ha with a concentrate supplementation of $600 \mathrm{~kg}$ of dry matter/cow. The factor that had the greatest influence on profitability was variability of milk price.

Key words: grazing intensity, concentrate supplementation, models, economic

Received March 28, 2017.

Accepted September 2, 2017.

${ }^{1}$ Corresponding author: elodie.ruelle@teagasc.ie

\section{INTRODUCTION}

With the end of the European Union milk quota regime in 2015, dairy farmers have an opportunity to expand their dairy enterprises unhindered for the first time in a generation. For most farmers, restrictions at a farm level moved from a scenario in which they are limited by milk quotas to a scenario in which some other features of the farm will be limiting. For most farmers, this will be land. Research has demonstrated that increasing stocking rate (SR) will result in an increase in milk production per hectare and at the same time will be associated with a reduction in postgrazing height, thus decreasing grass intake per cow and ultimately reducing milk production per cow (McCarthy et al., 2013) if not associated with an increase in grass growth or concentrate supplementation. Conversely, increasing the amount of concentrate fed will result in an increase in milk production per cow at any given SR. The increase is dependent on the level of initial underfeeding in the herd, mainly driven by the overall farm SR (McEvoy et al., 2008) as well as dairy cow genetics. For dairy farmers, the effect on performance of various strategies needs to be evaluated at farm level in terms of overall farm performance and, ultimately, economic performance. Indeed, the effect of SR and concentrate supplementation is highly dependent on the type of animal and the overall grass growth on the farm (Dillon et al., 2003). Dairy farms in Ireland in general have a type of animal that has been selected for a balance of milk production and fertility traits that are adapted to the Irish grazing system (e.g., compact spring calving, extended grazing season; Berry et al., 2014).

Farms are complex, and there is no easy way to calculate the perfect economic system due to the presence of many interactions. For example, optimal economic performance can change with variations in grass growth, differing SR, and variation in prices of milk and concentrates. To investigate the economically optimum strategies for a farm under various SR and for different amounts of concentrate feeding, the use of mechanistic models is beneficial. The models used must 
be capable of simulating the complex interactions of the system, including the effect of increasing fertilizer levels on grass growth; the effect of grazing severity on animal intake, milk production, and BCS; and the effect of all of these characteristics on farm profitability. Several models and scenarios have been developed and used in the dairy industry all over the world to answer complex industry questions in recent years (Schils et al., 2007; McDonald et al., 2013). Examples of such research in Ireland include investigating the effect of soil type and climatic conditions on overall farm profitability (Shalloo et al., 2004a), the effect of genotype and feed system on system profitability (McCarthy et al., 2007), the effect on profitability of introducing sexed semen technologies in cows and in heifers (Hutchinson et al., 2013a, b), and the effect on profitability of expansion of the dairy industry (McDonald et al., 2013). All of those studies used an Irish whole-farm model to evaluate different options with data obtained from empirical studies (Shalloo et al., 2004b). Models have been used in other countries to simulate the long-term effects of a technology or a strategy on a farm by simulating the technology over many years (Rotz et al., 1989). Schils et al. (2007) used the model DairyWise to explore future farm strategies for individual farms and for study groups of farmers working under similar environmental conditions.

In this study, 3 previously described models were used to evaluate 20 different options across different grazing systems and concentrate feeding levels. The models included a grass growth model, the Moorepark and St Gilles grass growth model (MoSt GG; Ruelle and Delaby, 2016; Ruelle et al., 2016b), which has been merged with an animal intake and performance model (Ruelle et al., 2015, 2016a). The outputs from those models have been combined into the Moorepark dairy systems model (MDSM; Shalloo et al., 2004b) to evaluate the overall effect of 20 options on the economic performance of the farm. The analysis was conducted with a cow that had been selected for a balance of traits encompassing both milk production and fertility over a 14-yr period (Berry et al., 2014).

The objective of this study was to evaluate the economics of expansion across different system options for dairy farmers in a post-European Union quota environment. Four different SR and 5 concentrate supplementation strategies were examined across a range of different milk and concentrate price scenarios.

\section{MATERIALS AND METHODS}

Three separate models were integrated to simulate the production system (Figure 1).

\section{Description of the 3 Models}

MoSt GG Model. The MoSt GG model is a dynamic model developed in $\mathrm{C}++$ (Ruelle and Delaby, 2016; Ruelle et al., 2016b) and based on the Jouven grass growth model (Jouven et al., 2006). A nitrogen submodel as well as a water submodel have been added to the Jouven grass growth model to create the MoSt GG model. The model simulates grass growth with a daily time step taking into account soil water and soil N dynamics. The model uses weather (temperature, solar radiation, and rainfall) and farm management (fertilization, harvesting, and grazing) information as inputs to complete the simulations.

Pasture-Based Herd Dynamic Milk Model. The pasture-based herd dynamic milk (PBHDM) model is a dynamic, stochastic agent-based model developed in $\mathrm{C}++$ (Ruelle et al., 2015). The PBHDM model comprises the herd dynamic milk model (Ruelle et al., 2016a) adapted for grazing conditions and management. Each animal and paddock are described and simulated individually on a daily basis. The model simulates all aspects of the life of an animal from birth to culling and death through several different submodels. The submodels included in the PBHDM model include fertility, intake, animal growth, BCS change, and milk production. The model simulates each individual animal at grazing and is dependent on the animal characteristics but also on grass availability and quality, with a decrease in animal intake during the defoliation process included in the model. Within the model, grassland management-based decision rules are included to ensure realistic simulations. Animals move from one paddock to another based on a fixed residency time in the paddocks or based on an objective postgrazing height that can be either fixed or dependent on the pregrazing height. The farm cover is evaluated daily and is compared with the requirement of the cattle. In situations in which there is an excess of farm cover on the overall farm, some paddocks can be allocated for silage conservation rather than grazed and vice versa if paddocks are closed for silage. In the case of grass deficit (subject to the management rules defined by the user), forage or concentrate supplementation can be added to the diet. The PBHDM model has been evaluated in terms of milk production, weekly BCS, grass harvested per hectare, pre- and postgrazing height, and residence time across 2 data sets in Ireland and France (Ruelle et al., 2015). The MoSt GG model has been incorporated within the PBHDM to predict directly the grass growth for each paddock in the model, thus reacting to the management and interacting with the animals.

MDSM. The MDSM (Shalloo et al., 2004b) is a stochastic budgetary simulation model with the objective 


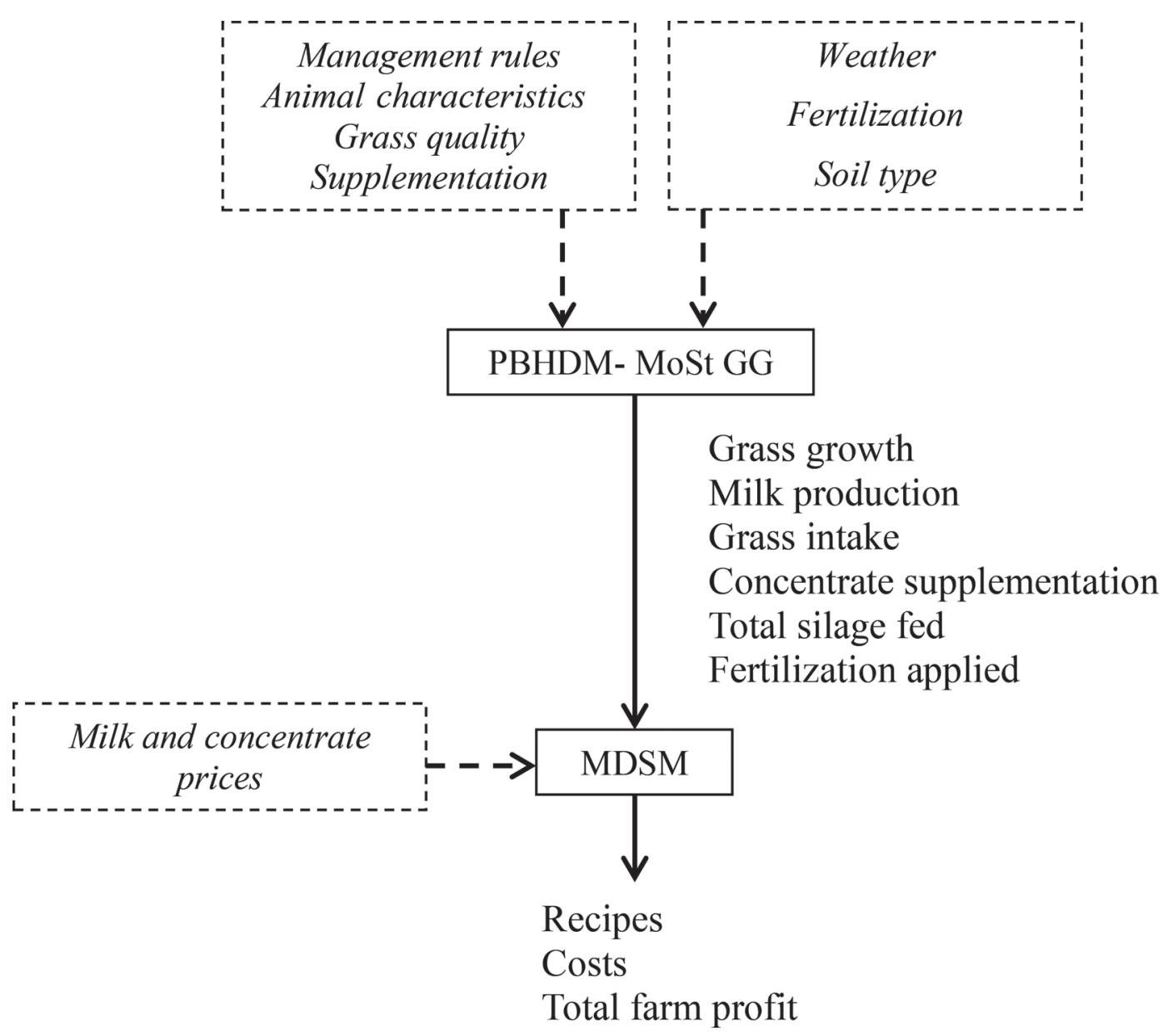

Figure 1. Flow diagram of the linkage of the models used to evaluate the effect of stocking rate and concentrate feeding rate on economics of Irish dairy farms. PBHDM = pasture-based herd dynamic milk model; MoSt GG = Moorepark and St Gilles grass growth model; MDSM $=$ Moorepark dairy systems model.

of simulating pasture-based milk production systems across a range of sustainability indicators, including profit when changes are made to the farm. The model can test the effect of various institutional, economic, and technical changes within the Irish dairy industry. Examples where the model has been used include the development of an economic-based grass selection ranking index (McEvoy et al., 2011) or the evaluation of different expansion strategies across a 15-yr time horizon (McDonald et al., 2013). The model integrates animal inventory and valuation, milk production, feed requirement, land and labor utilization, and economic analysis. The model takes into account the variable costs (fertilizer, contractor charges, medical and veterinarian, AI, silage, and reseeding), fixed costs (machinery running and maintenance, farm maintenance, car, telephone, electricity, and insurance), and commodity prices (calf, milk, and cow). Outputs from the model include the detailed costs and receipts, profitability, and physical outputs such as the feed budget from the overall farm.

\section{Scenarios}

The descriptions of the inputs used in the different simulations for each model are summarized in Table 1. For each simulation the farm size is fixed at 40 ha divided into 18 paddocks. Twenty main scenarios were analyzed: 4 SR $(2.3,2.6,2.9$, and $3.2 \mathrm{cow} / \mathrm{ha})$ combined with 5 concentrate supplementation levels [0, 180, 360, 600 , and $900 \mathrm{~kg}$ of concentrate $(\mathbf{C O N}) /$ cow per year]. The $\mathrm{N}$ fertilization was set at $210 \mathrm{~kg}$ of $\mathrm{N} /$ ha per year. Each scenario was simulated over $10 \mathrm{yr}$ of meteorological data to give 200 different simulations.

Utilization of the PBHDM-MoSt GG Model. The 20 scenarios were simulated over 10 yr (2004-2013), resulting in 200 different yearly grass growths with 10 


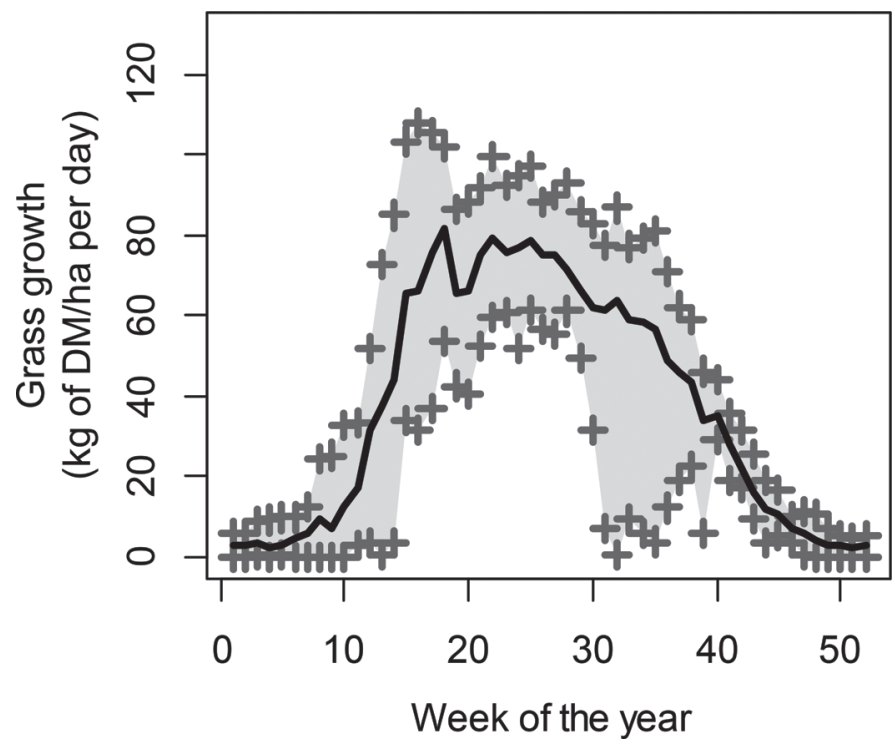

Figure 2. Representation of the average (black line) and minimum and maximum (cross) weekly grass growth ( $\mathrm{kg}$ of $\mathrm{DM} / \mathrm{ha}$ per day) across 200 simulations representing 4 different stocking rates and 5 concentrate supplementation strategies across 10 weather years. Gray represents the range.

yr of weather recorded in Moorepark, Ireland (N 52.17, $\mathrm{W}-8.27)$. Figure 2 represents the distribution of the average, maximum, and minimum of the 200 daily grass growths per week of the year.

For each grazing system, $25 \%$ of primiparous cows were included in the overall makeup of the herd. Monthly concentrate breakdown for the different scenarios is presented in Table 1 . The grazing season was set to start on February 10 and finish on November 20. The breeding season started on May 1 and ended on July 31. Cows were fed grass silage indoors when not lactating. The energy values of the feeds are expressed using the French net energy system (Faverdin et al., 2010; INRA, 2010) in unité fourragère lait (UFL) values, where $1 \mathrm{UFL}=1,700 \mathrm{kcal}$ of $\mathrm{NE}_{\mathrm{L}}$. The average energetic values of the feeds were $1.03 \mathrm{UFL} / \mathrm{kg}$ of DM concentrate, $0.8 \mathrm{UFL} / \mathrm{kg}$ of DM grass silage, and 0.97 $\mathrm{UFL} / \mathrm{kg}$ of grazed grass corresponding to profiles of feed quality measured over a prolonged period of time in Teagasc Moorepark (McCarthy et al., 2013). The rule to move the animals from one paddock to another was based on the objective postgrazing height, which was set at $4.5 \mathrm{~cm}$. The average genetic merit of cows included in the model was assumed to have a potential peak milk yield of $30 \mathrm{~kg}$ with a BW at calving of 550 $\mathrm{kg}$ for multiparous cows and $500 \mathrm{~kg}$ for primiparous cows. This would correspond to an average Irish cow (Holstein breed) that had been selected for a balance of traits encompassing both milk production and fertility over a 14-yr period (Berry et al., 2014).

Utilization of the MDSM. The MDSM was used to evaluate overall farm profitability using outputs simulated by the PBHDM models. The average performance over the $10 \mathrm{yr}$, including milk production, feeding levels, and average grass growth, was used as an input into the MDSM. The milk production per cow predicted by the PBHDM model was used as an input in the MDSM. This milk production has been corrected for death, culling, milk for calves, and nonsaleable milk to create the milk sales, which corresponds on average to $95 \%$ of the milk predicted by the PBHDM model.

All financial inputs included in the model were based on current costs and prices. The base milk price was included at 29.5 euro cents $(\mathbf{c}) / \mathrm{L}$ with the $\mathrm{A}+\mathrm{B}-\mathrm{C}$ multiple component pricing system used for milk payment (Geary et al., 2010). A flat-rate value added tax payment was included on milk sales at $5.2 \%$ based on current national policy. Concentrate costs were included

Table 1. Description of the input used for the 200 simulations representing 4 different stocking rates and 5 concentrate supplementation strategies across 10 weather years

\begin{tabular}{|c|c|c|c|c|c|}
\hline \multirow{2}{*}{$\begin{array}{l}\text { Variable } \\
\text { Farm size }\end{array}$} & \multicolumn{5}{|l|}{ Input $^{1}$} \\
\hline & \multicolumn{5}{|c|}{40 ha in 18 paddocks } \\
\hline Yearly average grass quality & \multicolumn{5}{|c|}{$1.00 \mathrm{FV}, 0.97 \mathrm{UFL}, 100 \mathrm{PDI}$} \\
\hline Silage supplementation & \multicolumn{5}{|c|}{$8 \mathrm{~kg}$ maximum (quality $=1.27 \mathrm{FV}, 0.80 \mathrm{UFL}, 80 \mathrm{PDI}$ ) } \\
\hline Grazing season & \multicolumn{5}{|c|}{ February 10 to November 20} \\
\hline Breeding season & \multicolumn{5}{|c|}{ May 1 to July 31} \\
\hline Objective postgrazing height $(\mathrm{cm})$ & \multicolumn{5}{|c|}{4.5} \\
\hline No. of months of concentrate feeding (starting on d 1 of lactation) & 0 & 3 & 4 & 5 & 6 \\
\hline Daily concentrate fed $(\mathrm{kg} / \mathrm{d})$ & 0 & 2 & 3 & 4 & 5 \\
\hline Total concentrate fed $(\mathrm{kg} /$ cow per year $)$ & 0 & 180 & 360 & 600 & 900 \\
\hline
\end{tabular}

${ }^{1} \mathrm{FV}=$ fill value; $\mathrm{UFL}=$ unité fourragère lait $\left(1 \mathrm{UFL}=1,700 \mathrm{kcal}\right.$ of $\left.\mathrm{NE}_{\mathrm{L}}\right) ; \mathrm{PDI}=$ protéine digestible dans l'intestin (Faverdin et al., 2010 , INRA, 2010). 
at $€ 250 / \mathrm{t}$ based on average national concentrate prices in 2016. Grass silage purchase costs were included at $€ 170 / \mathrm{t}$ based on consultation with industry experts. Fertilizer, veterinarian, and all contracting costs were based on the current industry averages. Sensitivity analyses were completed with milk prices of 24.5 and $34.5 \mathrm{c} / \mathrm{L}$, concentrate costs of $€ 200$ and $€ 300 / \mathrm{t}$, and silage costs of $€ 120$ and $€ 220 / t$ to determine how changes in those prices as key components of the system affected outcomes.

\section{RESULTS}

\section{PBHDM-MoSt GG Outputs}

Grass Growth. The average annual grass growth across all simulations was $12,390 \mathrm{~kg}$ of DM/ha. Grass growth increased slightly with increased concentrate supplementation (average grass growth of $12,351 \mathrm{~kg}$ of $\mathrm{DM} /$ ha for $0 \mathrm{CON}$ to $12,441 \mathrm{~kg}$ of $\mathrm{DM} /$ ha for 900 CON; Table 2) and with SR (average grass growth of $12,312 \mathrm{~kg}$ of DM/ha for $2.3 \mathrm{SR}$ to $12,468 \mathrm{~kg}$ of DM/ha for 3.2 SR; Table 3, Figure 3).

There were important variations among years in terms of grass growth, with a minimum of $10,397 \mathrm{~kg}$ of DM/ ha grown in 2011 for 0 CON-2.9 SR and a maximum of $15,352 \mathrm{~kg}$ of DM/ha in 2010 for $980 \mathrm{CON}-3.2 \mathrm{SR}$. The variation of grass growth among years is presented in Figures 2 and 4 . The grass growth increases slowly from February to reach its maximum in May (Figure 2), similar to recorded grass growth curves for Ireland.

Grass and Silage Intake. The average grass intake per cow was $2,703 \mathrm{~kg}$ of DM/cow and 7,409 $\mathrm{kg}$ of DM/ ha. The average silage fed per cow (including supplementation at grazing and indoor feeding for lactating and dry animal) was $1,090 \mathrm{~kg}$ of DM/cow corresponding to $3,015 \mathrm{~kg}$ of $\mathrm{DM} / \mathrm{ha}$. The grass intake per hectare and per cow decreased with increasing concentrate supplementation and ranged from an average of 2,816 $\mathrm{kg}$ of $\mathrm{DM} /$ cow and $7,745 \mathrm{~kg}$ of $\mathrm{DM} /$ ha for the $0 \mathrm{CON}$ simulation to $2,565 \mathrm{~kg}$ of DM/cow and $7,055 \mathrm{~kg}$ of DM/ ha for the $900 \mathrm{CON}$ simulations (Table 2, Figure 2). Similarly, increasing the concentrate supplementation led to a decrease of silage fed per cow from $1,115 \mathrm{~kg}$ of $\mathrm{DM}$ for $0 \mathrm{CON}$ to $1,067 \mathrm{~kg}$ of DM for $900 \mathrm{CON}$ and a decrease of silage fed per hectare from $3,067 \mathrm{~kg}$ of DM for $0 \mathrm{CON}$ to $2,933 \mathrm{~kg}$ of DM for $900 \mathrm{CON}$ (Table 2, Figure 2).

An increase in SR led to a decrease in grass intake per cow from 2,797 to $2,613 \mathrm{~kg}$ of $\mathrm{DM} /$ cow per hectare for 2.3 SR and 3.2 SR, respectively (Table 3, Figure 3). An increase in SR led to an increase in the grass intake per hectare from 6,433 to $8,362 \mathrm{~kg}$ of $\mathrm{DM} /$ ha for 2.3 SR and 3.2 SR, respectively (Table 3, Figure 3). An

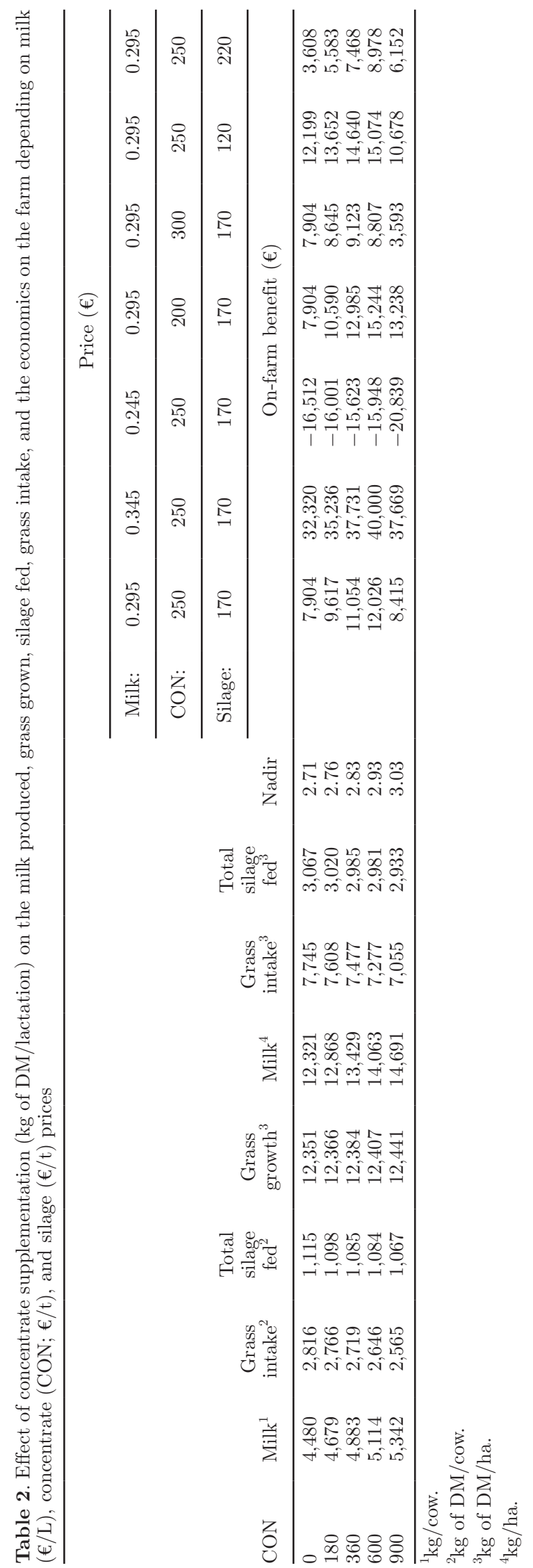


increase in SR led to an increase in the silage fed at both cow (from 1,018 to $1,160 \mathrm{~kg}$ of DM for $2.3 \mathrm{SR}$ and $3.2 \mathrm{SR}$, respectively) and hectare (from 2,340 to 3,712 $\mathrm{kg}$ of DM for 2.3 SR and 3.2 SR, respectively) levels.

The overall feed intake by the animal was relatively stable among years (Figure 4). However, the breakdown between grass intake and silage fed was variable. The maximum grass intake per cow was $3,110 \mathrm{~kg}$ of DM/ cow for $0 \mathrm{CON}-2.3 \mathrm{SR}$ in 2008, and the minimum intake was $1,777 \mathrm{~kg}$ of DM/cow for $900 \mathrm{CON}-3.2 \mathrm{SR}$ in 2011. The maximum silage fed was $1,811 \mathrm{~kg}$ of $\mathrm{DM} /$ cow for $0 \mathrm{CON}-3.2 \mathrm{SR}$ in 2011 , and the minimum silage fed was $831 \mathrm{~kg}$ of DM/cow for $180 \mathrm{CON}-2.3 \mathrm{SR}$ in 2009 . The maximum grass intake per hectare was $9,544 \mathrm{~kg}$ of $\mathrm{DM} /$ ha for $0 \mathrm{CON}-3.2 \mathrm{SR}$ in 2005, and the minimum was $4,895 \mathrm{~kg}$ of DM/ha for $900 \mathrm{CON}-2.3 \mathrm{SR}$ in 2011. The maximum silage fed was $5,796 \mathrm{~kg}$ of $\mathrm{DM} /$ ha for 0 CON-3.2 SR in 2011, and the minimum was $1,911 \mathrm{~kg}$ of DM/ha for $180 \mathrm{CON}-2.3 \mathrm{SR}$ in 2009 .

Animal Production. The increase of concentrate supplementation induced an increase in milk production from $4,480 \mathrm{~kg} / \mathrm{cow}$ and $12,321 \mathrm{~kg} / \mathrm{ha}$ for 0 CON to $5,363 \mathrm{~kg} / \mathrm{cow}$ and $14,691 \mathrm{~kg} / \mathrm{ha}$ for $900 \mathrm{CON}$. The response to concentrate was $1.1 \mathrm{~kg}$ of milk/ $\mathrm{kg}$ of concentrate between $0 \mathrm{CON}$ and $180 \mathrm{CON}$, which decreased to $0.8 \mathrm{~kg}$ of milk/ $\mathrm{kg}$ of concentrate between $600 \mathrm{CON}$ and 900 CON. The interaction with SR was minimal $(<0.1$ $\mathrm{kg}$ of milk production $/ \mathrm{kg}$ of concentrate variation in the response). The increase in SR led to a decrease in milk production per cow (range $=4,948 \mathrm{~kg}$ for 2.3 SR to 4,856 for $3.2 \mathrm{SR}$ ) and an increase in the milk production per hectare (range $=11,380 \mathrm{~kg}$ for $2.3 \mathrm{SR}$ to $15,539 \mathrm{~kg}$ for $3.2 \mathrm{SR}$ ).

Over all the different simulations, the minimum milk production per cow was $4,018 \mathrm{~kg}$ in 2011 for $0 \mathrm{CON}-3.2$ $\mathrm{SR}$, and the maximum was $5,440 \mathrm{~kg}$ in 2005 for 900 CON-2.3 SR. The minimum milk production per hectare was $9,743 \mathrm{~kg}$ in 2011 for $0 \mathrm{CON}-2.3 \mathrm{SR}$, and the maximum was $17,234 \mathrm{~kg}$ in 2008 for $900 \mathrm{CON}-3.2 \mathrm{SR}$.

\section{Economic Outputs}

Impact of the Variation of Prices. For the base simulation (milk price of $29.5 \mathrm{c} / \mathrm{L}$, concentrate price of $€ 250 / \mathrm{t}$, and silage price of $€ 170 / \mathrm{t}$ ), all farm scenarios had a positive net farm profit with an average of $€ 9,803$. The lowest farm profit achieved was $€ 3,661$ for $900 \mathrm{CON}-2.3 \mathrm{SR}$ and the highest was $€ 15,332$ for $600 \mathrm{CON}-2.6 \mathrm{SR}$. A decrease in milk price to $24.5 \mathrm{c} / \mathrm{L}$ led to an average decrease of net profit of $€ 26,788$ over all simulations compared with the base simulation. At $24.5 \mathrm{c} / \mathrm{L}$, the lowest farm profit was $-€ 26,455$ for $900 \mathrm{CON}-3.2 \mathrm{SR}$ and the highest was $-€ 10,805$ for 0 CON-2.3 SR. The increase in milk price to $34.5 \mathrm{c} / \mathrm{L}$ 
led to an average increase of net profit of $€ 26,455$ over all simulations compared with the base simulation. At this high milk price, the lowest farm profit was $€ 28,308$ for $900 \mathrm{CON}-2.3 \mathrm{SR}$ and the highest was $€ 43,081$ for $600 \mathrm{CON}-3.2$ SR. A decrease in the concentrate price to $€ 200 / t$ led to an average increase of $€ 2,189$ over all simulations compared with the base simulation. At the $€ 200 / \mathrm{t}$ concentrate price, the lowest farm profit was $€ 4,067$ for $0 \mathrm{CON}-3.2 \mathrm{SR}$ and the highest was $€ 18,374$ for $600 \mathrm{CON}-2.6 \mathrm{SR}$. An increase in the concentrate price to $€ 300 / \mathrm{t}$ led to an average decrease in the farm profit of $€ 2,189$ compared with the base simulation. At the $€ 300 / \mathrm{t}$ concentrate price, the lowest farm profit was $-€ 423$ for $900 \mathrm{CON}-2.3 \mathrm{SR}$ and the highest was $€ 12,289$ for $600 \mathrm{CON}-2.6 \mathrm{SR}$. A decrease in the silage purchase price to $€ 120 / t$ led to an average increase of the farm profit of $€ 3,446$. At the $€ 120 / \mathrm{t}$ silage purchase price, the lowest farm profit was $€ 3,661$ for $900 \mathrm{CON}-2.3 \mathrm{SR}$ and the highest was $€ 17,960$ for $600 \mathrm{CON}-3.2 \mathrm{SR}$. An increase in the silage purchase price to $€ 220 / \mathrm{t}$ led to an average decrease of the net profit of $€ 3,445$. At the $€ 220 / t$ silage price, the lowest net profit was $-€ 4,962$ for 0 CON-3.2 SR and the highest was $€ 14,529$ for 600 CON-2.6 SR.
SR: 2.3

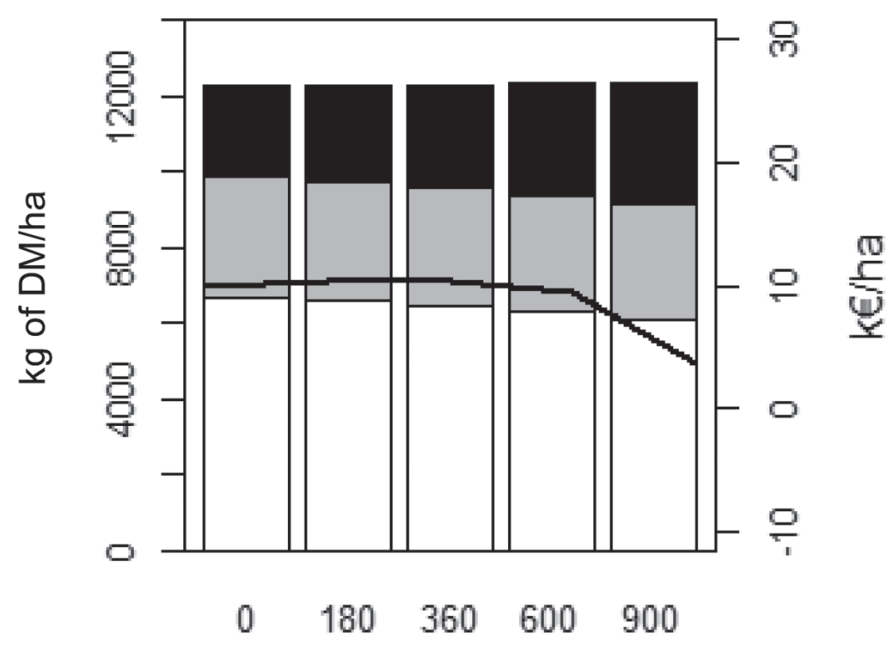

SR: 2.9

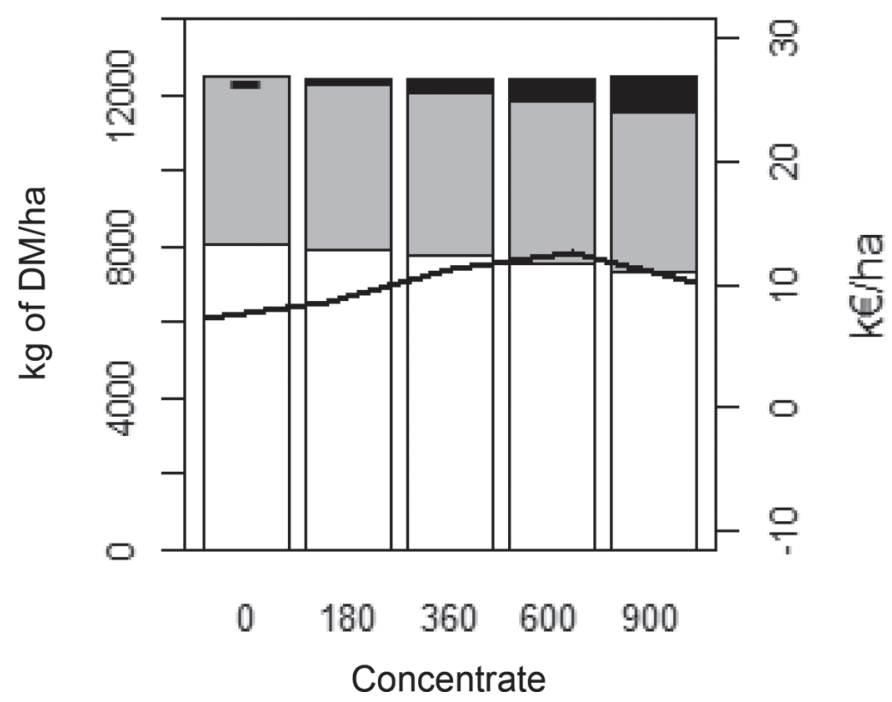

SR: $\mathbf{2 . 6}$

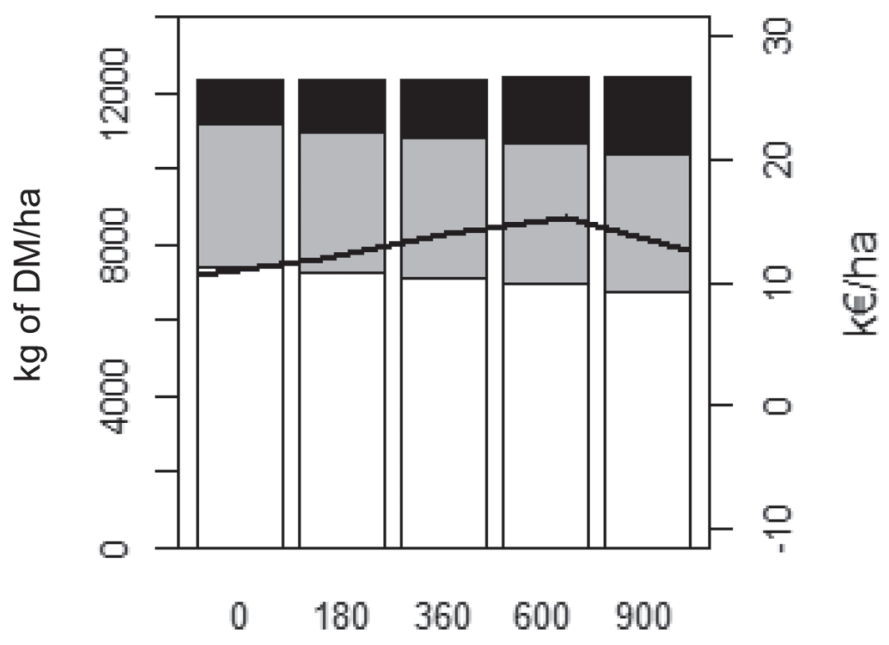

SR: 3.2

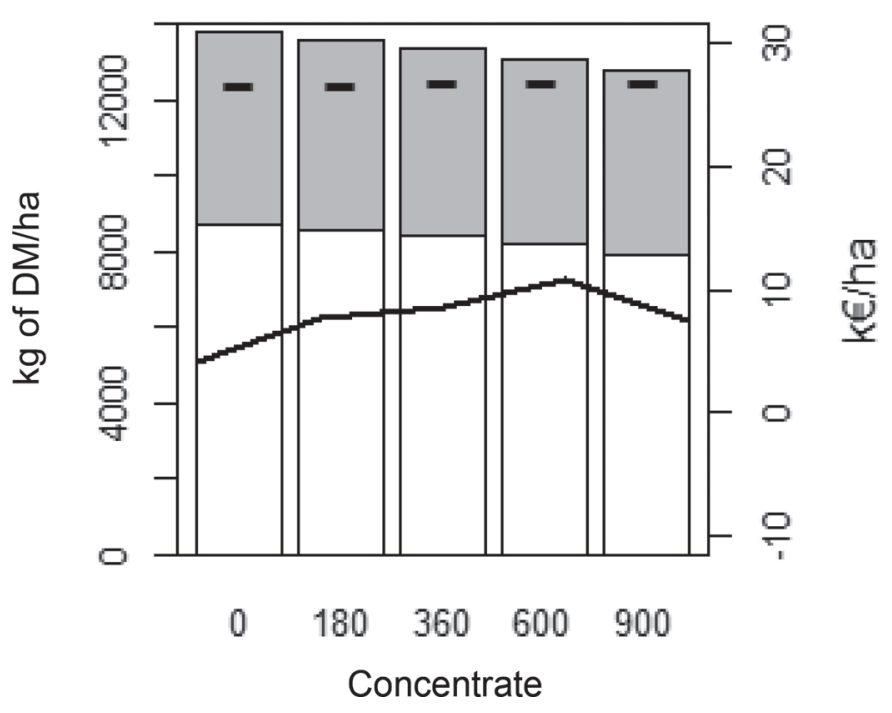

Figure 3. Proportion of grass intake (white) and silage fed per hectare of the grass grown per year (black) depending on the stocking rate (SR) and concentrate supplementation (average of the $10 \mathrm{yr}$ ) and silage fed (gray) and their consequences on the profitability of the farm (black line) in kilo euros $(\mathrm{k} €)$. 
Impact of the Concentrate and SR. On average across concentrate supplementation, the SR of 2.6 was the most profitable across virtually all combinations of prices. In general, farm profit decreased when the SR went over 2.6 cows/ha. The exceptions to this rule were in the case of a high milk price or a low silage purchase price, where SR 3.2 was the most favorable. On average across the SR levels, 600 CON was the most profitable for most of the different concentrate, silage, and milk price scenarios. For those scenarios, the increase in concentrate supplementation led to an increase in the farm profit until $600 \mathrm{CON}$, whereas continuing to increase concentrate supplementation to $900 \mathrm{CON}$ led to a decrease in the farm profit. The exception to that rule was in the case of a low milk price or a high concentrate price, where $360 \mathrm{CON}$ was the most profitable.

\section{DISCUSSION}

\section{Models and Modeling}

The present study, using models, described the effects of the variation of SR and concentrate supplementation on the agronomic and economic outputs of a farm. Through the integration of 3 different models, this study evaluated different options for farmers as milk quotas no longer constrain milk production in Ireland. In practice, the development and application of models to answer key industry questions such as this one are the only time- and resource-efficient way to provide direction through research for dairy farmers. Experimentally testing the scenarios examined here would require the

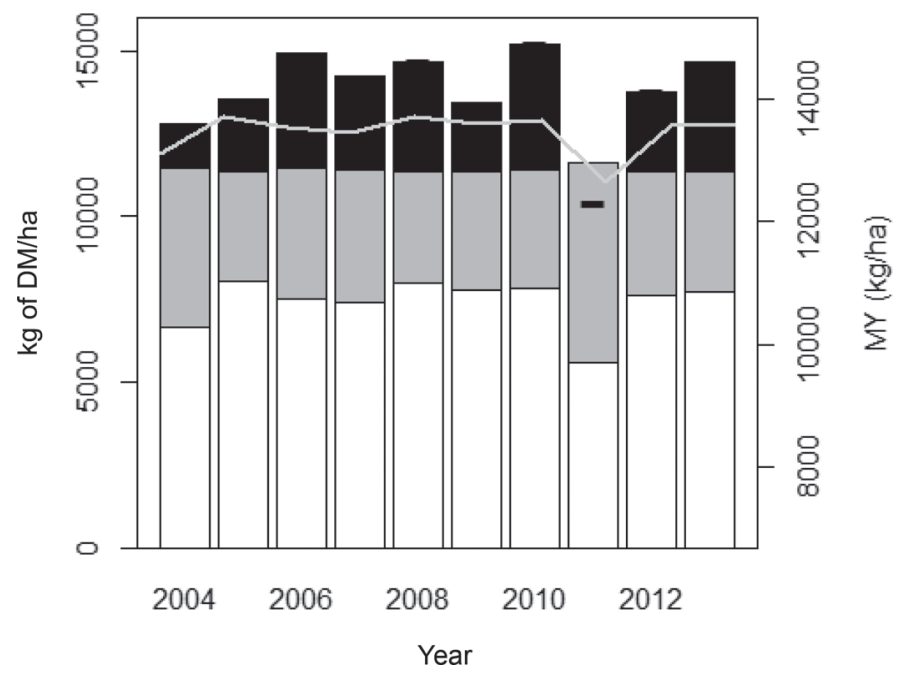

Figure 4. Proportion of grass intake (white) and silage fed (gray) per hectare of the grass grown per year (black) depending on the year (average of stocking rate and concentrate supplementation) and its consequences on the milk production per hectare (MY; light gray line). farm systems to be operated for several years to ensure the accuracy of the data created. Examples of where models were used to undertake similar exercises include DairyWise (Schils et al., 2007), which has been used to compare the energy use and greenhouse gas emissions in organic and conventional farming systems (Bos et al., 2014). Similarly, the DAFOSYM model (Rotz et al., 1989) has been used to determine the effect on annual net return of using automatic milking systems across farms of different sizes (Rotz et al., 2003) or to determine the effect of feeding strategy and protein supplements on the nitrogen loss and profitability on farm. The models in this study have been built to be dynamic and capable of following management rules that would be applied at farm level.

\section{Animal-Pasture Interaction}

The milk production increase with the increase in concentrate supplementation ranged across the simulation from 0.63 to $1.48 \mathrm{~kg}$ of milk $/ \mathrm{kg}$ of concentrate per cow. The lowest response of $0.63 \mathrm{~kg}$ in 2010 for $900 \mathrm{CON}-2.3$ SR corresponds to a year with good grass growth and a minimum requirement for supplementation (Figure 4). The maximum response was $1.48 \mathrm{~kg}$ of milk $/ \mathrm{kg}$ of concentrate in 2011 for 180 CON-3.2 SR, corresponding to a year with low grass growth and a very high requirement for silage supplementation (Figure 4). On average, as concentrate feeding level increased the response to concentrate reduced, and as the SR increased so too did the concentrate response. The responses on average were $1.11,1.13,0.96$, and $0.76 \mathrm{~kg}$ of milk $/ \mathrm{kg}$ of concentrate fed between 0 and 180, 180 and 360,360 and 600 , and 600 and 900 , respectively. In terms of the different SR, the responses were 0.97, 0.98, 1.00, and $1.01 \mathrm{~kg}$ of milk $/ \mathrm{kg}$ of concentrate (average across year and concentrate feeding level) for SR of 2.3, 2.6, 2.9, and $3.2 \mathrm{cow} / \mathrm{ha}$, respectively. These results in terms of concentrate response are in accordance with previously published results. For example, Delaby et al. (2003) reported responses of between 0.63 and $1.57 \mathrm{~kg}$ of milk/ $\mathrm{kg}$ of concentrate; similarly, Fulkerson et al. (2008) reported responses of between 0.63 and $1.63 \mathrm{~kg}$ of milk/ $\mathrm{kg}$ of concentrate. Other studies have reported lower overall responses (McCarthy et al., 2007), which ranged from 0.3 to $1 \mathrm{~kg}$ of milk/ $\mathrm{kg}$ of concentrate. Roche et al. (2006) showed responses that ranged between 0.2 and $1.1 \mathrm{~kg}$ of milk/ $\mathrm{kg}$ of concentrate, and Reis and Combs (2000) reported responses that ranged between 0.4 and $0.8 \mathrm{~kg}$ of milk/ $\mathrm{kg}$ of concentrate. These differences can be attributable to several factors, including base feed quantity, base feed quality, type of cow, time of year, and amount of concentrate fed (Buckley et al., 2000; Delaby et al., 2009). 


\section{Economics}

Across the different scenarios and prices, the most profitable system was generally $600 \mathrm{CON}-2.6 \mathrm{SR}$. With a high milk price or a low silage purchase price, 600 CON-3.2 SR was the most profitable; with a low milk price, $0 \mathrm{CON}-2.3 \mathrm{SR}$ was the most profitable. This highlights the fact that in case of a decrease in the milk price, self-sufficient systems are the most favorable despite not maximizing the output per cow or per hectare.

Overall, increasing grass utilization through increasing the SR of the farm has been associated with an increase in overall farm profit. This is in agreement with previous studies (Shalloo et al., 2009; Ramsbottom et al., 2015) that demonstrated that increasing the pasture harvested per hectare is associated with increased profitability per hectare. However, above SR 2.6 , with the grass growth achieved in this study, the farm is not capable of meeting the demand without purchasing additional feed, which is in agreement with other studies using different approaches (Ramsbottom et al., 2015).

However, these results are not extensive. If the analysis was completed with an animal selected for a higher milk production potential, it could be anticipated that these animals would produce a higher milk production response to concentrate than the type of cow simulated in this study (Fulkerson et al., 2008), which may change the conclusions. Response to concentrate has been shown to be highly dependent on the type of cow (Horan et al., 2005; Fulkerson et al., 2008); the choice of using relatively low-producing cows in this study was made to reproduce the type of cow common in Ireland. This type of cow has been selected for a balance of traits, including fertility and health, and therefore its response would be lower than that of a cow selected solely for milk production. The fact that the gain in milk production does not compensate the cost of the increase in concentrate supplementation for the higher concentrate supplementation may be different for higher producing dairy cows, especially at higher SR. However, the potential reduction in fertility performance expected from that type of cow would outweigh any potential milk production benefits (Shalloo et al., 2004c; McCarthy et al., 2007).

All the analyses have been based on the assumption of a fixed area of land that is owned, as there is difficulty in securing land adjacent to the milking platform in Ireland. Grass is the cheapest feed available to pasture-based farmers (Finneran et al., 2010). However, there are opportunities to increase grass growth at a farm level, with on average national grass growth of approximately $9,300 \mathrm{~kg}$ of $\mathrm{DM} /$ ha produced across dairy farms (Creighton et al., 2011). This study has demonstrated that dairy farmers can operate profitably at relatively higher grazing intensity while at the same time showing that the benefits of increasing concentrate supplementation are limited, similar to what has been shown previously (Shalloo et al., 2004c; McCarthy et al., 2007). Nationally, Irish dairy farms are on average stocked at approximately 2 cows/ha, and they feed approximately $900 \mathrm{~kg}$ of concentrate/cow (Hanrahan et al., 2017). Thus, there are opportunities to increase grass growth and reduce concentrate while at the same time increasing profitable milk production once the focus is on increased grass growth at the farm level. With anticipated increases in both input and output price volatility, it is expected that farm systems that are more reliant on grazed grass will be more resilient in the future, as has been presented here.

\section{CONCLUSIONS}

This study has compared the economic efficiency of 5 different concentrate supplementation strategies (0, $180,360,600$, or $900 \mathrm{~kg}$ of concentrate/lactation) and 4 different SR options $(2.3,2.6,2.9$, and 3.2 cow/ha). The outputs from this study have demonstrated that models can be useful when analyzing strategies for the dairy farm business. This study has demonstrated that systems of milk production built around matching the supply and demand of home-produced feed, minimizing the level of supplementary feed, were the most profitable and resulted in the least variability of profitability across different input and output prices.

\section{ACKNOWLEDGMENTS}

The authors acknowledge the financial support of the FP7 GreenHouseMilk Marie Curie project and the funding from the Research Stimulus Fund 2011 administered by the Department of Agriculture, Fisheries and Food (Dublin, Ireland; project 11/S/132).

\section{REFERENCES}

Berry, D. P., E. Wall, and J. Pryce. 2014. Genetics and genomics of reproductive performance in dairy and beef cattle. Animal 8:105121.

Bos, J. F. F. P., J. D. Haan, W. Sukkel, and R. L. M. Schils. 2014. Energy use and greenhouse gas emissions in organic and conventional farming systems in the Netherlands. NJAS Wagening. J. Life Sci. 68:61-70. https://doi.org/10.1016/j.njas.2013.12.003.

Buckley, F., P. Dillon, S. Crosse, F. Flynn, and M. Rath. 2000. The performance of Holstein Friesian dairy cows of high and medium genetic merit for milk production on grass-based feeding systems. Livest. Prod. Sci. 64:107-119. https://doi.org/10.1016/S0301 -6226(99)00167-0.

Creighton, P., E. Kennedy, L. Shalloo, T. Boland, and M. O'Donovan. 2011. A survey analysis of grassland dairy farming in Ireland, in- 
vestigating grassland management, technology adoption and sward renewal. Grass Forage Sci. 66:251-264.

Delaby, L., P. Faverdin, G. Michel, C. Disenhaus, and J. Peyraud. 2009. Effect of different feeding strategies on lactation performance of Holstein and Normande dairy cows. Animal 3:891-905.

Delaby, L., J.-L. Peyraud, N. Foucher, and G. Michel. 2003. The effect of two contrasting grazing managements and level of concentrate supplementation on the performance of grazing dairy cows. Anim. Res. 52:437-460.

Dillon, P., F. Buckley, P. O'Connor, D. Hegarty, and M. Rath. 2003. A comparison of different dairy cow breeds on a seasonal grass-based system of milk production: 1 . Milk production, live weight, body condition score and DM intake. Livest. Prod. Sci. 83:21-33.

Faverdin, P., R. Delagarde, L. Delaby, and F. Meschy. 2010. Alimentation des vaches laitières. Pages 23-58 in Alimentation des Bovins, Ovins et Caprins. Editions Quae. INRA, Versailles Cedex, France.

Finneran, E., P. Crosson, P. O'Kiely, L. Shalloo, D. Forristal, and M. Wallace. 2010. Simulation modelling of the cost of producing and utilising feeds for ruminants on Irish farms. J. Farm Manag. 14:95-116.

Fulkerson, W. J., T. M. Davison, S. C. Garcia, G. Hough, M. E. Goddard, R. Dobos, and M. Blockey. 2008. Holstein-Friesian dairy cows under a predominantly grazing system: Interaction between genotype and environment. J. Dairy Sci. 91:826-839. https://doi .org/10.3168/jds.2007-0147.

Geary, U., N. Lopez-Villalobos, D. J. Garrick, and L. Shalloo. 2010. Development and application of a processing model for the Irish dairy industry. J. Dairy Sci. 93:5091-5100. https://doi.org/10 3168/jds.2010-3487.

Hanrahan, L., A. Geoghegan, M. O'Donovan, V. Griffith, E. Ruelle, M. Wallace, and L. Shalloo. 2017. PastureBase Ireland: A grassland decision support system and national database. Comput. Electron. Agric. 136:193-201. https://doi.org/10.1016/j.compag 2017.01.029.

Horan, B., P. Dillon, P. Faverdin, L. Delaby, F. Buckley, and M. Rath. 2005. The interaction of strain of Holstein-Friesian cows and pasture-based feed systems on milk yield, body weight, and body condition score. J. Dairy Sci. 88:1231-1243. https://doi.org/10.3168/ jds.S0022-0302(05)72790-9.

Hutchinson, I. A., L. Shalloo, and S. Butler. 2013a. Expanding the dairy herd in pasture-based systems: The role for sexed semen use on virgin heifers. J. Dairy Sci. 96:1312-1322.

Hutchinson, I. A., L. Shalloo, and S. Butler. 2013b. Expanding the dairy herd in pasture-based systems: The role of sexed semen use in virgin heifers and lactating cows. J. Dairy Sci. 96:6742-6752.

INRA. 2010. Alimentation des Bovins, Ovins et Caprins. Editions Quae. INRA, Versailles Cedex, France.

Jouven, M., P. Carrere, and R. Baumont. 2006. Model predicting dynamics of biomass, structure and digestibility of herbage in managed permanent pastures. 1. Model description. Grass Forage Sci. 61:112-124.

McCarthy, B., L. Delaby, K. M. Pierce, A. Brennan, and B. Horan. 2013. The effect of stocking rate and calving date on milk production of Holstein-Friesian dairy cows. Livest. Sci. 153:123-134. http://dx.doi.org/https://doi.org/10.1016/j.livsci.2013.01.013.

McCarthy, S., B. Horan, P. Dillon, P. O'Connor, M. Rath, and L. Shalloo. 2007. Economic comparison of divergent strains of Holstein-Friesian cows in various pasture-based production systems. J. Dairy Sci. 90:1493-1505. http://dx.doi.org/https://doi.org/10 $.3168 /$ jds.S0022-0302(07)71635-1.

McDonald, R., L. Shalloo, K. Pierce, and B. Horan. 2013. Evaluating expansion strategies for startup European Union dairy farm businesses. J. Dairy Sci. 96:4059-4069.

McEvoy, M., E. Kennedy, J. P. Murphy, T. M. Boland, L. Delaby, and M. O'Donovan. 2008. The effect of herbage allowance and concentrate supplementation on milk production performance and dry matter intake of spring-calving dairy cows in early lactation. J. Dairy Sci. 91:1258-1269. https://doi.org/10.3168/jds.2007-0710.
McEvoy, M., M. O'Donovan, and L. Shalloo. 2011. Development and application of an economic ranking index for perennial ryegrass cultivars. J. Dairy Sci. 94:1627-1639. https://doi.org/10.3168/jds $2010-3322$.

Ramsbottom, G., B. Horan, D. P. Berry, and J. R. Roche. 2015. Factors associated with the financial performance of spring-calving, pasture-based dairy farms. J. Dairy Sci. 98:3526-3540. https://doi .org/10.3168/jds.2014-8516.

Reis, R. B., and D. K. Combs. 2000. Effects of increasing levels of grain supplementation on rumen environment and lactation performance of dairy cows grazing grass-legume pasture. J. Dairy Sci. 83:2888-2898. https://doi.org/10.3168/jds.S0022-0302(00)75189 $-7$.

Roche, J. R., D. P. Berry, and E. S. Kolver. 2006. Holstein-Friesian strain and feed effects on milk production, body weight, and body condition score profiles in grazing dairy cows. J. Dairy Sci. 89:3532-3543. https://doi.org/10.3168/jds.S0022-0302(06)72393 $-1$.

Rotz, C. A., D. R. Buckmaster, D. R. Mertens, and J. R. Black. 1989. DAFOSYM: A dairy forage system model for evaluating alternatives in forage conservation. J. Dairy Sci. 72:3050-3063.

Rotz, C. A., C. U. Coiner, and K. J. Soder. 2003. Automatic milking systems, farm size, and milk production. J. Dairy Sci. 86:41674177. https://doi.org/10.3168/jds.S0022-0302(03)74032-6.

Ruelle, E., and L. Delaby. 2016. The Moorepark grass growth model: Application in grazing systems. Pages 409-411 in The Multiple Roles of Grassland in the European Bioeconomy. Proceedings of the 26th General Meeting of the European Grassland Federation, Trondheim, Norway. Wageningen Academic Publishers, Wageningen, the Netherlands.

Ruelle, E., L. Delaby, M. Wallace, and L. Shalloo. 2016a. Development and evaluation of the herd dynamic milk model with focus on the individual cow component. Animal 10:1986-1997.

Ruelle, E., D. Hennessy, C. Paillette, and L. Delaby. 2016b. Modelling the surface of a paddock affected by urine and faeces deposition during grazing by dairy cows. Pages 489-491 in The Multiple Roles of Grassland in the European Bioeconomy. Proceedings of the 26th General Meeting of the European Grassland Federation, Trondheim, Norway. Wageningen Academic Publishers, Wageningen, the Netherlands.

Ruelle, E., L. Shalloo, M. Wallace, and L. Delaby. 2015. Development and evaluation of the pasture-based herd dynamic milk (PBHDM) model for dairy systems. Eur. J. Agron. 71:106-114. https://doi .org/10.1016/j.eja.2015.09.003.

Schils, R. L. M., M. H. A. de Haan, J. G. A. Hemmer, A. van den Polvan Dasselaar, J. A. de Boer, A. G. Evers, G. Holshof, J. C. van Middelkoop, and R. L. G. Zom. 2007. DairyWise, a whole-farm dairy model. J. Dairy Sci. 90:5334-5346. https://doi.org/10.3168/ jds.2006-842.

Shalloo, L., P. Dillon, J. O'Loughlin, M. Rath, and M. Wallace. 2004a. Comparison of a pasture-based system of milk production on a high rainfall, heavy-clay soil with that on a lower rainfall, freedraining soil. Grass Forage Sci. 59:157-168. https://doi.org/10 $.1111 / j .1365-2494.2004 .00415 . x$.

Shalloo, L., P. Dillon, M. Rath, and M. Wallace. 2004b. Description and validation of the Moorepark dairy system model. J. Dairy Sci. 87:1945-1959. https://doi.org/10.3168/jds.S0022-0302(04)73353 $-6$.

Shalloo, L., B. W. Kennedy, M. Wallace, M. Rath, and P. Dillon. 2004c. The economic impact of cow genetic potential for milk production and concentrate supplementation level on the profitability of pasture based systems under different EU milk quota scenarios. J. Agric. Sci. 142:357-369. https://doi.org/10.1017/ S002185960400437X.

Shalloo, L., S. O'Donnell, and B. O'Brien. 2009. Economic analysis of a rotary and herringbone parlour at different size of dairy enterprise. Moorepark Dairy Production Research Centre, Fermoy, Co. Cork, Ireland. 